\title{
Catholic School Identity and the New Evangelization
}

\author{
William Sultmann \\ Oceania Province, Christian Brothers; Adjunct \\ Professor, University of Queensland \\ wfsultmann@edmundrice.org
}

\author{
Raymond Brown \\ Griffith University, \\ Queensland \\ ray.brown@griffith.edu.au
}

\begin{abstract}
Catholic school identity has been identified as a priority topic in the field of Catholic education. This article explores Catholic school identity within a changing context and in light of the challenges of the new evangelization. A Leximancer analysis of the aggregated verbal responses of eight focus groups across Australia ( $\mathrm{n}=73$ ) highlighted four high frequency concepts (school, students, community, and people) as foundational to Catholic school identity. Subsequently, Interpretative Phenomenological Analysis (IPA) detailed the discourse expressions for each of these concepts and assigned a core principle to summarize the narrative. The principles that summarized the discourse concepts were: school (shared sacred mission); students (personal evangelization for life); community (being and building a Christian community); and people (authentic witness). Findings revealed the breadth, depth and uniqueness of Catholic school identity, the interaction of discourse concepts and their expression as core pillars of Faith, Learning, Leadership, Formation and Community. Discussion attended to the consideration of identity pillars as a focus for spirituality in support of the new evangelization.
\end{abstract}

\section{INTRODUCTION}

Catholic school identity entails the "constants that define Christianity in its missionary nature" (Bevans \& Schroeder, 2004, p. 33), or more broadly, 'the worldview': “what people, individually or collectively, know and believe, feel and value” (D’Orsa \& D’Orsa, 2010, p. 72). Identified as an 'extraordinarily timely topic' in the first half of the third millennium, the exploration of Catholic school identity is said to constitute a project akin to "shaping the future of the Church and of society" (Miller, 2007 video recording).

\section{Catholic school context and profile}

The experience of continuous change within Catholic schools in Australia was articulated by the Bishops of New South Wales and the Australian Capital Territory (NSW \& ACT) as constituting a crossroads (2007, p. 3). That is, a situation had arisen where demonstrable changes were apparent and new pathways needed to be considered. Irrespective of the appropriateness of image, research reveals that the profile of the Catholic school has changed and that both choice of pathway (being at a crossroads) and discernment as to mission (addressing the frontier) demand consideration.

(i) Faith representation

The Catholic population of Australia, together with its Catholic school population, has grown in recent decades. However, within this growth there has been a decrease in the proportion of Catholic 
students in Catholic schools. The national trends are staggering: 51\% of Catholics attend government schools and 25\% of enrolments in Catholic schools are other than Catholic (NCEC, 2010).

(ii) Trends in socio-economic status

The research of Pascoe (2007) and the more recent analysis of Bishop Anthony Fisher (2006) and Brian Croke (2007) draw attention to the nature of the overall enrolment patterns within Catholic schools, specifically in terms of socio-economic status. They conclude that within a Tradition of providing a preferential option for the poor and primarily catering for students from Catholic families, the profile is now such that: "poorer Catholic children are increasingly attending State schools; wealthier Catholic children are increasingly attending non-Catholic private schools; and middle income other than Catholic children are increasingly attending Catholic schools” (Fisher, 2006, p. 4).

(iii) Religion and spirituality (international)

An international study (Search Institute, 2008), on how young people (7000 youth between 12 and 25 years of age across 17 countries and 6 continents), illustrate substantial shifts and national variation in commitment to religion and spirituality. On a positive note, the majority of youth (93\% internationally) believe there is a spiritual dimension to life. Religion was seen as rule based, whereas spirituality was perceived as an experience of the 'heart'. With respect to international comparisons, Australia ranked highest in declaring an absence of spirituality (47\% compared to the group mean of $24 \%)$.

(iv) Spiritual engagement (Australia)

A study into the attitudes of Generation Y (people born, 1981-1985) confirmed the level of disinterest in faith and spirituality among young Australians (Mason, Singleton, \& Webber, 2008). Significant among the findings were a general low level of interest and involvement in religion and/or spirituality (17\%), with $51 \%$ of respondents declaring a belief in God, 32\% being unsure and 17\% indicating nonbelief. Overall, while some importance was given to Church and school influences on faith and spiritual development, the pattern identified factors of family (44\%), friends (15\%), religious organizations (14\%), school (6\%), and youth organizations (4\%) as most significant.

(v) Staff profile

The presence of lay staff within Catholic schools has grown exponentially across recent decades. Moreover, examining the decline in Clerical and Religious numbers across five Australian provinces (down $19 \%$ and $46.5 \%$ respectively across the period 1970 to 2004), Susan Pascoe (2007) paints a picture of a changing cohort of leadership at the level of parish and a corresponding shift in the presence of Religious Brothers and Sisters in leadership within the life of schooling. At the same time, the pattern of teachers who are not of the Catholic faith (approximating 25\%), and those with no specific faith formation (63\%), has grown to levels necessitating specific formation interventions (Elliott \& Rush, 2011).

(vi) Parent priorities 
A survey of Catholic, state and independent school parents into factors influencing school selection yielded consistent priorities irrespective of the education sector (Sultmann, Rasmussen \& Thurgood, 2003). Choice centered on: care of students, the quality of teaching, school discipline, parental consultation, moral development, vision and values. For the group of parents who had elected Catholic schooling, the more traditional criteria were rated comparatively low in response to the question 'what is absolutely essential?': faith development (46\%), pastoral care and concern (47\%), and religious education (39\%). This profile was reinforced in the report of Kennedy, Mulholland and Dorman (2010, p. iv) which confirmed the priority and satisfaction of parents as to "positive relationships within safe, caring, concerned school communities”.

Variability in religious affiliation, socio-economic status, faith practice and spirituality, staff profile and parent expectations led Bishop Anthony Fisher to conclude that the current context necessitates engaging a new horizon for Catholic schools. The argument is made for a response of mission outreach and cultural awareness. It is premised upon engaging the signs of the times, a view of the Faith as life-giving, and a renewed commitment to formation founded on understanding and witness (Fisher, 2006).

\section{New Evangelization}

The Church's agenda for the third millennium is challenging and comprehensive. The Church is called to draw upon its Traditions and recognize the complexity and needs of the current social reality, while proclaiming the fundamental imperative to focus on Christ and the Gospel. It is within this context that Pope John Paul II introduced the concept of a new evangelization, as a means for interpreting the Gospel with new vigor and ardor, recognizing the status of humanity, the culture of our times and analyzing human needs (for an overview of the 'new evangelization' as detailed in Vatican II documents see Engebretson, 2010). The concept implied that countries and societies that were once evangelized had lost the vigor of faith, and needed to receive the message in a fresh and vital way in order to win them back to Christ (Porteous, 2008).

A Catholic understanding of evangelization remains vague. "For many Catholics, the term is rather foreign sounding; it may actually be an alienating word for some people who connect evangelization only with tent meetings, bible thumping, or a hard sell to preaching or sharing the Gospel” (Brennan, 1987, p. 5). Conscious of such an appreciation, Brennan concludes, nonetheless, that "evangelization is the central mission of the Church in general and of individual Christians in particular” (1987, p. 5). Moreover, the Second Vatican Council described the whole Church as 'missionary and the work of evangelization as a basic duty of the people of God' (Flannery, 1998, Decree on the Church's Missionary Activity, p. 35). Subsequently, and more precisely, Pope Paul VI spoke of evangelization as the Church's deepest identity: “evangelization is in fact the grace and vocation proper to the Church, her deepest identity; she exists in order to evangelize” (1975, p. 14). 
Evangelization is argued to possess four overall themes: it refers to every activity in which the world is transformed according to the Gospel; it embraces any ministerial activity by which the Church is built up; incorporates all activities of Gospel proclamation and explanation; and is a first step in the process of religious education. Within this context, evangelization entails "the proclamation of the Gospel, to Christians and non-Christians, in an attempt to awaken and/or nourish faith” (Brennan, 1987, p. 6). The position signals witness, formation of the heart and service. Apart from this impact on the person, the influence of evangelization on culture is equally significant as the Gospel seeks to convert the personal and collective consciences of people, the activities in which they engage, and the lives and concrete milieu in which they live.

The success of the new evangelization is first geared to witness; to live as Christ lived in the pursuit of all that is noble and good. This witness finds expression in the home, school, parish, community and virtual communities where values are lived in the day-to-day and ordinary experiences of life. In this way, faith becomes more than the system of beliefs that offer meaning; it becomes the reason for the practice of life. Pope Benedict adds that the Christian message is not only 'informative' but 'performative' and as such “the Gospel is not merely a communication of things that can be known it is one that makes things happen and so is life-changing. The one who has hope lives differently; the one who has hope has been granted the gift of a new life” (Benedict XVI, 2007, p. 2).

An appreciation of the new evangelization as involving witness calls for new ways of sharing the faith in the complex and dynamic ecology of the Catholic school. The new evangelization engages the planned religious education curriculum enacted within the school classroom and the more subtle religious education curriculum experienced in the culture/ethos of the school. Key to the challenge of the new evangelization therefore is an appreciation of the school's foundational identity and those strategic and personal practices which might nurture this. Clearly, the call is for the Catholic school to be a centre for the new evangelization which engages culture in the delivery of the religious education curriculum and within the religious life of the school. It entails "proclaiming the Gospel anew, nurturing 'seeds of faith' in a context of freedom and yet being 'up front' about educational and catechetical goals” (NSW \& ACT Bishops 2007, pp. 12-13). These challenges are immense, specifically at a time when significant diversity exists within the population of the Catholic school and the extent of staff participation in faith practices. In light of these challenges, the focus on identity offers a strategic response to what is most significant. That is, what is valued in terms of identity and the spirituality that is implied by the enactment of the new evangelization. It is the purpose of this article to explore Catholic school identity within a changing context and in light of the challenges of the new evangelization and the implications for spirituality. 


\section{METHOD}

\section{Participants and Process}

Data was gained from a sample of eight schools, chosen because they are reflective of the diversity of a Catholic school network, because they each have a significant history of Catholic Education provision founded on Religious Institute governance and management and because the participants from each of these schools were in positions of significant influence in the school and volunteered their services to the project. The project engaged a total of 73 participants in a series of workshops. Each workshop comprised approximately 8 to 10 participants, was facilitated consistently and possessed a common format for data generation and recording. Participants included: at least one member of the school leadership team; Board members or nominees; the mission Coordinator; staff representatives with formation in the tradition of the school; and parents, normally members of the Parent Council. Data gathering focused on two inter-related questions: "Which program structures, processes, or events in the life and work of our school are intrinsic to identity? And...... what is it that we do that makes our school different and special”? (NPCSG, 2003, p. 8). Verbal data from each of the workshop groups was filed digitally and subjected to a Leximancer Analysis to identify key concepts and to Interpretative Phenomenological Analysis (IPA) to assess the discourse around these concepts.

\section{Analysis Tools}

Leximancer is a 'data mining and visualization tool' (Leximancer Manual, 2005) which analyses text and displays the extracted information visually via a 'concept map.' The concept map displays main concepts and their relationships with other concepts and permits a more detailed directed search of the data. The key to Leximancer interpretation is the notion of concepts -- collections of words that travel throughout the text. These concepts are reported in terms of how frequently they occur in sentences and their frequency of occurrence compared with a dominant concept. Leximancer also identifies and presents the associated text that accompanies the concepts identified from the text.

IPA attempts to "unravel the meaning contained in accounts through a process of interpretative engagement with text and transcripts” (Smith, Jaman, \& Osborn, 1999, p. 189). Overall, the process entails discrete but connected stages of data analysis: Stage 1 - Recording of key data; Stage 2 Generating theme titles; Stage 3 - Integration through assignment of a principle. The task of the IPA researcher is to try and understand the participants' world, and to describe what it is like. The second aim is to develop a more overtly interpretative analysis which positions the initial 'description' in relation to a wider social, cultural, and perhaps even theoretical, context. IPA is concerned with “understanding the person-in-context, and exploring persons' relatedness to, or involvement in, the world” (Larkin, Watts, \& Clifton, 2006, p. 110). In short, it involves a systematic analysis and interpretation of lengthy and complex verbal data in a way to give expression to meaning and strategy. 


\section{RESULTS AND DISCUSSION}

A Leximancer analysis of the aggregated transcriptions from the eight focus groups, a data pool of nine thousand words, generated 24 concepts. As shown in Table 1, concepts of significance are listed in relation to the dominant concept which is recorded as $100 \%$. The absolute count is also given for each concept; this count being the number of times the concept appears in the overall text.

Table 1

Identity concepts from aggregated focus group narratives

\begin{tabular}{|l|c|c|}
\hline Concept & Absolute Count & Relative Count \\
\hline School & 295 & $\mathbf{1 0 0 . 0 \%}$ \\
\hline Students & 279 & $\mathbf{9 4 . 5 \%}$ \\
\hline Community & 191 & $\mathbf{6 4 . 7 \%}$ \\
\hline People & 148 & $\mathbf{5 0 . 1 \%}$ \\
\hline Staff & 127 & $43.0 \%$ \\
\hline Life & 107 & $36.2 \%$ \\
\hline Sense & 101 & $34.2 \%$ \\
\hline Structures & 100 & $33.8 \%$ \\
\hline Education & 92 & $31.1 \%$ \\
\hline Values & 79 & $26.7 \%$ \\
\hline
\end{tabular}

The dominant identity concept is that of School, with Students, Community and People being the next three most highly weighted associated elements within the discourse. Also evident from other identity elements is the breadth of view that exists with respect to an understanding of identity. The similarity of concepts also suggests significant overlap among the concepts and raises the expectation of repetition in the verbal data to be found in the associated text passages.

Words and language which travel with the designated concept are presented in text passages arising from the Leximancer analysis. These accompanying passages permit a discourse analysis in terms of an interpretation of what the concept entails. Within the pool of the 24 reported concepts, an IPA was conducted on those concepts and associated text passages which bore a greater than $50 \%$ relationship, or relative count, to the primary aspect of identity derived from the Leximancer analysis. The results of stages two and three of the discourse process are reported in Table 2 as a summary of the narrative, and in Table 3 as a summary of weighted concepts, identity themes and integrative principles.

The identity concept of School was fostered through expressions of tradition, integration and participation; Students through individualization, religious dimension, holistic outcomes and pastoral care; Community through formation of a faith and model community; and People through emphasis on the person and the pervasiveness of values (Table 2). The overall principles which were aligned with the identity concepts and themes were: School - shared sacred mission; Students - personal 
evangelization for life; Community - being and building Christian community; and People - authentic witness (see Table 3).

Table 2

Identity concepts, themes and narratives from focus group responses

\begin{tabular}{|l|l|}
\hline Concept & \multicolumn{1}{|c|}{ Theme and Narrative } \\
\hline School & $\begin{array}{l}\text { Tradition: foundations in history with hallmarks of inclusion and as a place of } \\
\text { contact for being Church. } \\
\text { Integration: a hands-on, engaged and grounded leadership steeped in Gospel and } \\
\text { charism. } \\
\text { Participation: participation in fullness of life with expectations of engagement } \\
\text { through values, service and leadership influence. }\end{array}$ \\
\hline Students & $\begin{array}{l}\text { Individualization: seen in personal story, inclusion, curriculum/ adaptation and } \\
\text { outreach. } \\
\text { Religious dimension: an environment where the Gospel is lived, authentic to a } \\
\text { charism within Church and expressed through prayer and liturgy. } \\
\text { Holistic outcomes: students empowered with personal skills, opportunities, } \\
\text { capacity for community contribution and transition support. } \\
\text { Pastoral care: provision of service underpinned by relevant curriculum, } \\
\text { relationships, parent involvement, social justice experience and a nurturing } \\
\text { environment. }\end{array}$ \\
\hline Community & $\begin{array}{l}\text { Faith community: faith expression as an authentic Christian community. } \\
\text { Modeling: faith expression as leaven within wider community. }\end{array}$ \\
\hline People & $\begin{array}{l}\text { Dignity: the significance of people and the engagement of all. } \\
\text { Pervasive values: authentic people in continuing Christian service. }\end{array}$ \\
\hline
\end{tabular}

Table 3

IPA summary of focus group responses

\begin{tabular}{|l|c|l|l|}
\hline Concepts & Frequency & \multicolumn{1}{|c|}{ Themes } & Principles \\
\hline School & $100 \%$ & $\begin{array}{l}\text { Tradition } \\
\text { Integration } \\
\text { Participation }\end{array}$ & Phared sacred mission \\
\hline Students & $94.5 \%$ & $\begin{array}{l}\text { Individualization } \\
\text { Religious dimension } \\
\text { Holistic outcomes } \\
\text { Pastoral care }\end{array}$ \\
\hline Community & $64.7 \%$ & $\begin{array}{l}\text { Faith community } \\
\text { Model community }\end{array}$ & $\begin{array}{l}\text { Being and building Christian } \\
\text { community }\end{array}$ \\
\hline People & $50.1 \%$ & $\begin{array}{l}\text { Dignity of person } \\
\text { Pervasive values }\end{array}$ & Authentic witness \\
\hline
\end{tabular}

The responses of the eight focus groups reveal a comprehensive naming of identity. At the intuitive level, the findings presented as predictable of the culture of a typical school. However, from a deeper analysis of the identity concepts through IPA, what is noticeable is the uniqueness of this 'school life' as it pertained to experiences within a Catholic school.

The dominant identity concept, School, was articulated through the expressions of tradition, integration and participation. 'Tradition' revealed a connection with a unique school story with 
characteristics of inclusion, preferential option for the poor and a view of the school as a place of Church. The expression of school as 'integration' identified Catholic schooling as being liberating, energized by charism, and unified by concepts of holism, community, and the grounded and distributive nature of leadership found in the Gospel and relationships. The third expression of school as 'participation' also reinforced a culture of participative practices and engagement through service and outreach arising from values. The conclusion as to the overall nature of this unique culture of the Catholic school was expressed in the principle of 'shared sacred mission'.

The second identity concept, Students, also offered a particular perspective to the nature of the educative experience of Catholic schooling. Central to this was the uniqueness of the person and personal story, and the motivation to recognize and adapt learning to meet individual differences. The intentional curriculum was identified as possessive of a religious dimension with key elements of Gospel, Church and charism being integrated with pastoral care as a core practice. Outcomes for students were registered as personal and community growth. As predicted, identity expressions were found to overlap and yet the overall integrative principle of personal evangelization for life, while possessing its own distinctiveness with a focus on learning, reflected an alignment and a logical development from a 'shared sacred mission'.

The third identity concept, Community, extended the earlier themes and again reinforced the uniqueness of culture within the Catholic school. The expression of community as a place where faith is shared and lived was evident in the themes of faith community and model community. The primacy of the faith community was evidenced in practical terms through the theme of inclusion as integral to a living and vibrant faith community. The identity principle of 'being and building a Christian community' aligned with Catholic school vision and the nature of learning and teaching found in earlier identity principles.

The final identity concept extracted for comment, People, offers a level of integration and additional alignment to the concepts already outlined. The overall principle of 'authentic witness' reinforces the dignity accorded to people, colleagues, parents and staff; together with the pervasiveness of values arising from belief systems. These themes find expression in education as a means of Christian service with the associated implication that authenticity of practice is reflective of vision, learning processes and community commitments. Notably, authentic witness is identified as applicable to all within the community, is viewed as an expression of leadership and is connected to practices and attitudes which are linked to on-going formation. In light of the breadth of meaning attached to the concept, particularly its sub-division into narratives around leadership and formation, it was subdivided and re-named as Leadership and Formation. 


\section{GENERAL DISCUSSION}

\section{New Evangelisation for the classroom and school}

The focus of this article is on how a cross section of eight Catholic school communities view identity. As such our findings are general in that they focus on not just the teacher - although most of the participants were teachers and certainly teacher conscious. Notwithstanding this, we have not isolated the views of teachers nor conducted classroom observations. In this light we can only speculate - and potentially signal the need for more detailed and focused research.

In broad terms the New Evangelisation calls for new processes, images and ideas as to sharing the faith. It is the same faith but communicated in contemporary times. The research reported in this article offers certain advantages to attaining this goal. For example, within the research, identity as a construct is given a face, a story, a language, a way to go about spirituality in the school. The findings of the research confirm the relationship between identity and the implications of the New Evangelisation as being holistic - it is never just about a student's needs, a teacher's approach, a school's curriculum or a community's expectation. The new evangelisation provides a foundational challenge to nurture spirituality and so align both personal and professional endeavour with the identity of the school.

The identity themes of Faith, Learning, Community, Leadership and Formation underline what is significant to the life of a Catholic school. Moreover, the findings point to formation content and process, specifically in terms of nurturing this life through an authentic spirituality. In practical terms, spirituality is "what faith looks like in everyday attitudes and behaviours" (Dreyer, 1996, p. 13). It enables an integration of faith with life and a recognition of, and conversion to, a particular way of living. "Authentic contemporary spirituality is therefore not about something additional or even something new. It is not meant to take us out of anywhere, but should give depth, meaning and resonance to the ordinary in daily life" (Neidhart, 1997, p. 20).

Faith: Called to a Liberating Mission

A foundational pathway and continuing horizon for the expression of spirituality is the alignment of one's personal spirituality with the school's identity. The call to the liberating mission of the Catholic school provides an invitation into the person and message of Christ whereby the individual and community are able to learn and witness, and so engage the privilege of being 'salt' and 'leaven' within the kingdom of God, the vision of Christ (Paul XVI, 1965, p. 32). The call to mission invites an ever deepening appreciation of the spiritual, ecclesial, social, and wider communitarian life of the Catholic school. 
The challenge of the first pathway of spirituality involves nurturing and aligning personal spirituality with school mission, and recognizing that in both there is the potential for congruence and engagement of the sacred. This is a discernment process built on continuing reflection (Treston, 2005) in which the call to educate is drawn from a view of the world that is not distracted by the forces of narcissism (preoccupation with self), pragmatism (an excessive focus on work), and consumerism (unbridled restlessness for things that might fulfill desire).

\section{Learning: Ministering a Holistic and Meaningful Curriculum}

Complementing a role in mission is a pathway of spirituality that seeks to embed Catholic school identity within the totality of learning and teaching experiences. This second pathway is summarized as ministering a holistic and meaningful curriculum; inclusive of a quality religious education program, the development of relationships and engagement with culturally acceptable domains of learning.

The authentic practice of ministry within the life of the school is argued by D'Orsa (2010) to necessitate an appreciation and critique of learning as it unfolds. Key to this is the relationship between the 'knower' and knowledge, the criteria for knowledge selection and the processes of its acquisition. Within a context of Catholic school identity which holds Christ as the model for human aspiration, learning is built around relationships. In addition, curriculum content and process which are aligned to the Gospel is argued as critical if a worldview as to Catholic school identity is to be persuasive (D’Orsa \& D’Orsa, 2010). For learning to be authentic, the integration and alignment of pedagogical practices with the selection of curriculum becomes paramount. The process of 'grassroots theology', whereby the community pursues discernment around the nature of its teaching and learning, provides a mechanism from which choices emanate and critique flows. Spirituality which is intent upon structuring and delivering learning in this light constitutes the essence of ministering a holistic and meaningful curriculum. In this light, the content of the curriculum becomes as important as the means by which it is shared relationally.

\section{Community: Celebrating a Religious Tradition}

A third pathway of spirituality involves the celebration of the school's religious dimension found in the educational climate, the personal development of each student, the relationship established between culture and the Gospel, and the illumination of all knowledge with the light of faith (RDECS). Sharkey (2002) summarizes this expression as attentiveness to a ministry of the Word and a ministry of Witness. Teaching the Word is performed through the delivery of a quality Religious Education curriculum and associated faith-based activities, while Witness to the Word is pursued 
through the elucidation of appropriate values across all curriculum areas together with the quality of social and emotional relationships. The efficacy of nurturing spirituality through the religious dimension has not only impacted the immediate outcomes of growth in faith awareness and practice but is also reported in terms of student performance (Flynn, 1985), values learning (Crawford \& Rossiter, 2006) and social-emotional wellbeing (Bird and Sultmann, 2010).

Spirituality that is supportive of the religious dimension entails not only formal and communitarian practices but also the interior life of faith inclusive of the practices of presence, discernment, and empowerment. Presence entails the opening of self up to God's entry into life; discernment involves the processes of listening and reflecting within the diversity of possibilities; and empowerment involves the promotion of wellbeing within the world of the creature and Creator. This pathway of spirituality that celebrates the religious dimension in formal religious experiences and interior engagement is one that holds community as central. It is built around communion with God and celebrates this gift collectively and personally.

Leadership: Releasing the Spirit in Organizational Life

A fourth pathway for the practice of spirituality within the Catholic school nurtures the life of the Spirit as a source of wisdom. Fundamental to this practice is the concept of Church and an acceptance of the Church and school as being a pilgrim people on a journey to truth in being. Spirituality in this light seeks to experience God through the work of the Spirit.

Leadership of a Spirit-centred culture will facilitate opportunities for people to participate and share wisdom, be open to the dynamism of change and seek opportunities for development. It will nurture a culture where people are more important than things, structures, money, status or power, and where the values of love, compassion and justice take centre stage (Nolan, 1987). It is Spirit which draws from the ministry of Christ. It is a spirituality that binds together and provides quality to behaviours of diverse kinds. It provides the 'glue' which holds all organizational sub-systems together. Its summary goal is the release of the Spirit in organizational life in the context of creating a faith-centred, dynamic, open and interdependent system, which is supportive and responsive to the culture of the age grounded in the Tradition of faith.

Formation: Engaging Continuous Renewal

Formation, the fifth pathway of spirituality in support of Catholic school identity, is characterized by continuous renewal in the life of the Spirit. The effectiveness of continuous renewal begins with the willingness of the individual and the community to commit to formation. The Second Vatican 
Council, specifically in the Declaration on Christian Education, recognized the responsibility conferred on lay Catholics towards formation, while subsequent commentary has reinforced that it is central to a relevant life of faith and is therefore no longer optional within the Catholic school (Crawford \& Rossiter, 1994).

Personal formation in spirituality begins with an exploration of one's beliefs and values, 'our functioning anthropology' (Groome, 1988 p. 71) and progressively moves towards growth in the spirituality of imperfection (Rohr, 1997). This is a way of depicting a journey with and to God that entails abandonment to the will of the Father, a letting go of things that distract from a life of love and truth, and the development of trust in God who loves deeply at a personal level.

Complementing renewal in personal spiritual terms is the concept of continuous renewal of the Catholic school as an organization. This is argued to arise ideally from aligning culture with mission and the pursuit of four interdependent goals (Drucker, 1998). The first goal is to examine and establish the nature of how 'work' is done, particularly as part of a larger whole. The implication is that partnerships, alliances and joint ventures will be necessary for mission to be achieved. The second goal resides in the way 'work' is organized and the nature of the workforce. The implication is for an increasing emphasis on sharing responsibilities and identifying means for communication, cooperation and accountability. The third goal involves the need for the organization to become more self-regulatory, that is, to align practices (e.g., appointments, promotions, placements, incentives) to the values of the organization. Finally, the fourth goal involves generating an 'outside in' culture which seeks to establish what external information is necessary to perform the organization's role.

The nurturing of formation, at personal and community levels, has the same and unique goal of living in accord with the Gospel. Renewal, in both forms, begins with conversion, involves an appreciation of Church mission, while responsive to contemporary needs. Moreover, it presumes and promotes a connection with the Divine which not only seeks an experience of the sacred through contemplative dialogue but holds prayer as central. This engagement with the Divine provides the fundamental connection among the spiritual pathways and underlines the importance of prayer as 'a way of faith' (Freeman, 2010: recording).

\section{Future Research}

While the research reported in this article set out to explore what was considered as central to the identity of the Catholic school, conclusions remain tentative due to the constraints and limitations of the data. While overall numbers were adequate, the sample size of 73 could be expanded. In addition, focus group participants were somewhat unique. Participants were largely supportive of the school and independent of the classroom. As such, it would be valuable to gain perspectives from a different sample, specifically of teachers and a cross-section of the parent body. Moreover, direct observation 
of classroom practice as a means for validating and adding practical exemplars of ideas and expectations would be of value.

\section{REFERENCES}

Benedict XVI (2007). Spe salvi: Encyclical hope saves. http://www.vatican. va/holyfather/benedictxvi/encyclicals.

Bevans, S. B. and Schroeder, R. P. (2004). Constants in context: A theology of mission for today. Maryknoll, New York: Orbis Books.

Bird, K. A. and Sultmann, W. (2010). Social and emotional learning: Reporting a system approach to developing relationships, nurturing well-being and invigorating learning. Education and Child Psychology, 27 (1), 143-55.

Brennan, P. J. (1987). The evangelizing parish: Theologies and strategies for renewal. Allen, Texas: Tabor Publishing.

Buckingham, J. (2010). The growth of religious schooling. http://www.abc.net.au.

Crawford, M. and Rossiter, G. (1994). Staff spirituality - it’s not just for religious anymore._Momentum, $13-17$.

Crawford, M. and Rossiter, G. (2006). Reasons for living: Education and young people's search for meaning, identity and spirituality. Camberwell, Victoria: ACER Press.

Croke, B. (2007). Australian Catholic schools in a changing political and religious landscape. In G. R. Grace and J. M. O’Keefe, (Eds). (2007). International handbook of Catholic education: Challenges for school systems in the $21^{\text {st }}$ century. Parts one and two. The Netherlands: Springer.

D. D’Orsa, J. and D’Orsa, T. (2010). Explorers, guides and meaning-makers: Mission theology for Catholic educators. The Broken Bay Institute Mission and Education Series. Mulgrave, Victoria: John Garratt Publishing.

Dreyer, E. (1996). Spirituality more easily found in the world than in Churches. National Catholic Reporter, 9-11.

Drucker, P. (1998). How to prosper in the new economy. Forbes Global Business Finance. October, $52-63$.

Elliott, M and Rush, K (2011). The new religion curriculum: Strategic plan 2011-2015. Brisbane, Australia: Catholic Archdiocese of Brisbane.

Engebretson, K. (2010). The new evangelization and religious education in Catholic schools. Religious Education Journal of Australia, 26(1), 22-26.

Fisher, A. (2006). Purposes of Catholic secondary schools today. Address to Catholic Secondary Schools Association of NSW. Sydney, Australia: Catholic Education Office.

Flannery, A. (1998). Vatican council II: The conciliar and post conciliar documents vol II.

Flynn, M. (1985). The effectiveness of Catholic schools. Sydney: St Paul Publications.

Freeman, L. (2010). What is contemplative prayer? Audio Series._Keynote Address. Pray 2010.

Brisbane: Catholic Archdiocese of Brisbane. 
Grace, G. R. and O’Keefe, J. M. (Eds). (2007). Catholic schools facing the challenges of the $21^{\text {st }}$ century: An overview. International handbook of Catholic education: Challenges for school systems in the $21^{\text {st }}$ century. Parts one and two. The Netherlands: Springer.

Groome, T. (1988). Educating for life: A spiritual vision for every teacher and parent. Allan, Texas: Thomas More Press.

Kennedy, J., Mulholland, J, and Dorman, J. (2010). Queensland Catholic education commission consultancy project. An investigation of the issues that affect the decisions of Catholic families in low socio-economic circumstances in Queensland when choosing schools for their children. Banyo, Queensland: Australian Catholic University.

Larkin, M., Watts, S. and Clifton, E. (2006). Giving voice and making sense in interpretative phenomenological analysis. Qualitative Research in Psychology, 3, 102-20.

Leximancer Manual. (2005). http:www.leximancer.com Version 2.5.

Mason, M., Singleton, A. and Webber, R. (2008). The spirit of generation Y: Young people's spirituality in a changing Australia. Mulgrave, Victoria: John Garratt Publishing.

Miller, J.M. (2007 video recording). Directions for Catholic educational leadership in the $21^{\text {st }}$ century. Keynote Address. The Fourth International Conference on Catholic Educational Leadership. Sydney Australia. ACU National.

National Planning Committee for Schools Governance. (2003). Identifying the characteristics of an Edmund Rice school: Report on profile school consultations. Melbourne: Christian Brothers Australia.

Neidhart, H. (1997). Spirituality and the ministry of leadership - icing or leaven? Catholic School Studies. 70 (1), 20 - 22.

Nolan, A. (1987). Jesus before christianity. London: Darton Longman and Todd.

Pascoe, S. (2007). Challenges for Catholic education in Australia. In G. R. Grace and J. M. O’Keefe, (Eds). (2007). International handbook of Catholic education: Challenges for school systems in the $21^{\text {st }}$ century. Parts one and two. The Netherlands: Springer.

Paul VI. (1975). Apostolic exhortation Evangelii Nuntiandi: On evangelization in the modern world. Homebush, NSW: St. Paul Publications.

Porteous, J. (2008). (Ed.). The new evangelization: Developing evangelical preaching. Ballan, Victoria: Connor Court Publishing.

Rohr, R. (1997). Spirituality of imperfection. Audio Series. Cincinnati, Ohio: St Anthony Messenger Press.

Sharkey, P. (2002). Building our capacity and commitment. In D. Duncan and D. Riley, (Eds). Leadership in Catholic education. Sydney: Harper Collins.

Smith, J. A., Jaman, M., and Osborn, M. (1999). Doing interpretative phenomenological analysis. In M. Murray and K. Chamberlain (Eds). Qualitative health psychology: Theories and methods. London: Sage. 
Sultmann, W. F., Thurgood, G. and Rasmussen, B. (2003). What parents are thinking: Some reflections on choices for schooling. Catholic School Studies, 76(2), 16-20.

Treston, K. (2005). The reflective teacher. Brisbane: Creation Enterprises. 